\title{
Diatoms from Middle Miocene Continental Deposits of Primorye
}

\author{
Olesya Yu. Likhacheva \\ Far East Geological Institute Far Eastern Branch Russian Academy of Sciences, Vladivostok, Russia \\ Email: olesyalikh@gmail.com
}

Received April 2014

\begin{abstract}
Diatoms from Middle Miocene deposits of Khanka Lake's northwestern shore (Primorye) were studied using light and scanning microscopes. The analyses of diatom flora composition and species diversity showed that there was a dominace of several taxa that made possible the recognition of two diatom complexes. The lower complex differs from the upper one by higher species diversity, by presence of many subtropical diatoms and absence of pronounced dominant species. Differences between the complexes can be explained by the progressing climatic cooling and predominance of fluvial-lakustrine sedimentation over the typically lake one due to development of a wide system of river valleys.
\end{abstract}

\section{Keywords}

Miocene, Diatoms, Stratigraphy, Paleoclimate

\section{Introduction}

Diatom unicellular algae with external siliceous frustules are widely used in biostratigraphy and paleoclimatic reconstructions due to their sensitivity to environmental changes (Jousé, 1962; Douglas, Smoll, 1999; Pushkar, Cherepanova, 2001; Pushkar et al., 2013). Not only ecological structure of diatom paleocenosis and number of valves found in sediments, but also morphological features of phenotypes can at the same time be considered as a reaction of taxa on variations in living conditions (Cherepanova et al., 2010).

The Middle Miocene diatoms-containing continental deposits are wide spread on the territory of the Russian Federation. They have been studied in areas of the Russia's east geographically close to Primorye: West Siberia Lowland, near Lake Baikal, Transbaikalia and in the south of Far East Region (Glezer et al., 1974). The most thoroughly investigated are diatoms from sedimentary rocks of the Vitim Plateau; here, Middle Miocene diatom complex with dominating Aulacoseira Thwaites and Tetracyclus Ralfs has been recognized (Rasskazov, 2007). Diatoms from the coeval deposits of Tunkinskaya basin were studied by Cheremisinova (1973). Among multiplicity of species found there, there were determined genera Aulacoseira and Coscinodiscus Ehrenberg. Likhoshvay E.V. later carried out additional researches of diatoms from these deposits and has specified species which were belonged to several taxa (Likhoshway et al., 1997).

The objective of the present study was diatom flora from sedimentary strata of the Khanka depression (Primorye) which evolution was going in changing climate environments of the Middle Miocene. 


\section{Materials and Methods}

Material for studying represented 35 samples selected personally by the author from the Middle Miocene sedimentary rocks of erosion scarp on the Khanka Lake's western shore among settlements Turiy Rog and Novokachalinsk (Figure 1), as well as samples which were kindly given by Prof. V.S. Pushkar. All of them are rich in the well-preserved diatom flora.

The sedimentary rocks of the erosion scarp are composed of gravel, sandstone, thin-laminated tuffaceous siltstone and diatomite; they occur among underlying coal-bearing beds of Upper Oligocene age and the overlapping Upper Pliocene clays.

The suggestion to reckon this new stratigraphic unit to the Miocene sedimentary complex was given by B.I. Pavlyutkin (Pavlyutkin et al., 2004) based on the integrated study of sufficiently thick band of sediments (more than $200 \mathrm{~m}$ ) which were naturally outcropped on the Khanka Lake's western shore. Stratigraphic thickness of the strata is presented by the well-exposed suite of the same name. At the present time stratigraphic position of the studied strata remains a subject of discussion between geologists and paleobotanists. According to Decisions of the 4-th Interdepartmental stratigraphy meeting (The resolution..., 1994), this rock unit has been referred to the Bikinsky stratigraphic unit rather than to the Tavrichansky or Prikhankaisky horizons.

Within the stratum, three types of rocks are distinguished: pebbles in a sandy clay matrix, composed weathered rock and thin-layer tuffaleurolite with rare pebbles. Rock layers are gently bended (up to $2^{\circ}$ ) to the south and southeast. They are underlain, with an uncertain contact, by the poorly carboniferous deposits of the Upper Oligocene and are overlapped by red clays of the Upper Pliocene.

Technical processing of samples and their preparation for analyzing under a light microscope was in accordance to a generally accepted procedure (Glezer et al., 1974). If there was a lack of diatom valves in sedi- ments, the samples were exposed to heavy cadmium liquid treatment (density-2.6).

Taxonomic analysis of diatom flora, investigation of ecological structure of paleocenosis, measuring of diameter and height of bending valves have been conducted with the help of Axio Lab.A1 and Axioskop 40 Carl Zeiss light microscopes, at magnification x 2000, and with the use of immersion liquid. Fine structure of diatom shells was analyzed using the Carl Zeiss EVO 40 scanning microscope (magnification, up to x 15000) owned by Institute of Soil Biology FEB RAS.

The author uses here a classification of diatoms accepted by Russian diatomologists (Glezer et al., 1992), considering revision made for a number of species and genera (Kuzmin et al., 2009; Krammer, 1991; Krammer, Lange-Bertalot, 1991; Khursevich, 1994; Williams, 1989, 1996).

\section{Results and Discussion}

The analysis of taxonomic composition of flora, its species diversity and a dominance of several taxa allows distinguishing two diatom complexes within the Novokachalinskaya suite (Figure 1).

The lower diatom complex is confined to the bottom and middle parts of the sequence (points 9146-9149) and is characterized by relatively high diversity: 75 species that belong to 41 genera, lack of pronounced domination of any kind of species except two: Aulacoseira praegranulata (Jousé) Simonsen var. praegranulata f. praegranulata (Figure 2(K)) and A. praegranulata var. praeislandica f. praeislandica (Simonsen) Moisseeva (Figure 2(M)), which form tuffaceous diatomite layers.

This complex has been first described by V.S. Pushkar and M.V. Cherepanova (Pavlyutkin et al., 2004). Repeated sampling and redefining of species diversity has given clearer view of stratigraphic occurrence of diatoms in the sequence. It concerned first of all the matter of distribution of curvata forms of ancient Aulacoseira. In the Novokachalinsky complex, this form is represented by A. praegranulata var. praeislandica f. curvata (Jousé) Moisseeva (A. praegranulata var. praegranulata f. curvata (Jousé) Simonsen (Figure 2(N))—to a lesser extent) and by A. italica var. italica f. curvata (Pant.) Dav. which are first appeared in this stratigraphic interval.

Secondly, new species of genus Actinocyclus Ehrenberg (Figure 2(G)) and may be first Mesodictyon Theriot et Bradbury (Figure 2(L)) are distinguished here. Mesodictyon were earlier referred to a genus Coscinodiscus (Jousé, 1952; Moisseeva, 1971) and later to Pontodiscus Temniskova-Topalova et Sheshukova-Poretzkaya (Temniskova-Topalova et al., 1981; Moisseeva, 1995) and were considered as typical representatives of late Miocene and Pliocene only.

Characteristic complex of diatoms from the lower layers of stratigraphic sequence of Novokachalinskaya suite is represented by: Actinella brasiliensis Grunow (Figure 2(C)), Aulacoseira praegranulata var. praegranulata f. 


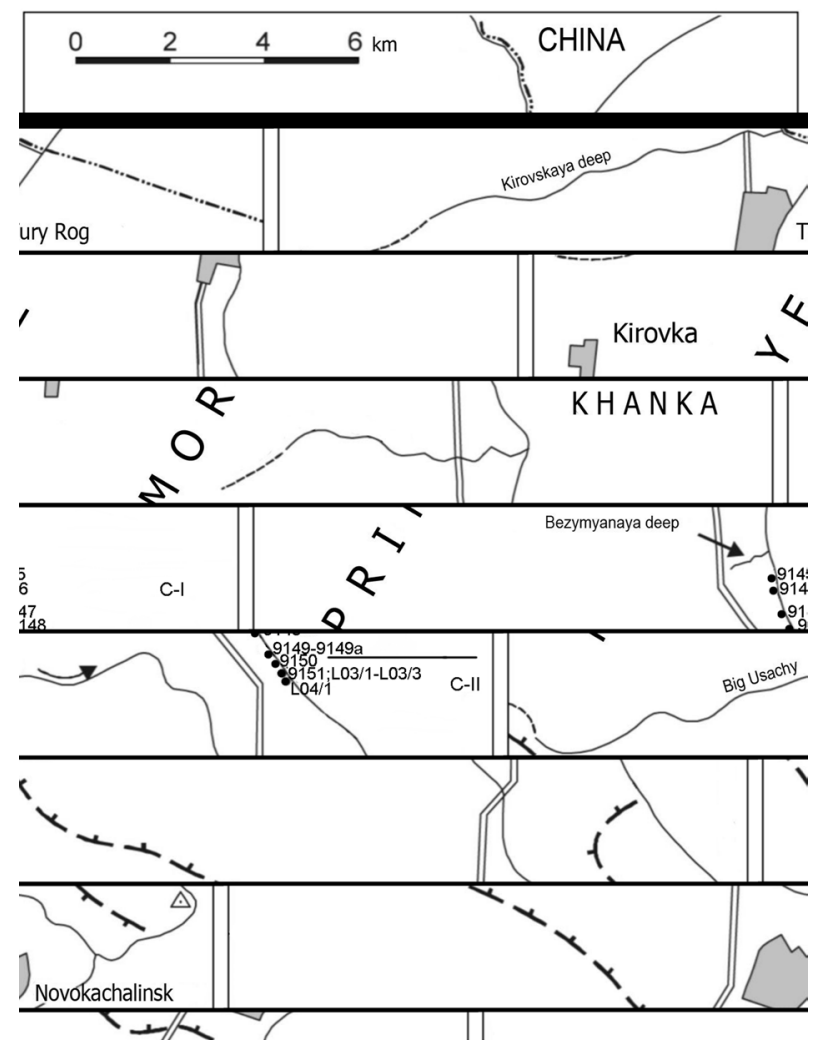

Figure 1. The stratotype of Novokachalinskaya suite (by Pavlutkin et al., 2004) with this paper author's modifying: 91459151, L03/1-L03/3, L04/1-location of the sampling points; C-I -lower complex, C-II-upper complex.

praegranulata, A. praegranulata var. praeislandica f. praeislandica, Ellerbeckia arenaria var. teres (Brun) R.M. Crawford (Figure 2(H)-(J)), Fragilariforma bicapitata (Mayer) D.M.Williams et Round (Figure 2(A)), Fragilaria miocenica Jousé var. miocenica (Figure 2(B)), Gomphonema miocenica Moiss., Melosira undulata (Ehr.) Kütz. var. undulate (Figure 2(D)), Miosira jouseana (Moisseva) Krammer, Lange-Bert. et Schiller (Figure 2(O)), M. areolata (Moisseva) Khurs., Staurosira construens Ehrenb. (Figure 2(E)), S. venter (Ehrenb.) Kobayasi (Figure 2(F)), S. elliptica (Schumann) D.M.Williams et Round, Tetracyclus glans (Ehrenb.) Mills). Age data obtained for this complex range in the interval of 18.1 - 14.9 Ma (Pavlyutkin et al., 1993, 2004).

The analysis of ecological structure of the complex suggests a conclusion about sublittoral environment of its formation in a sufficiently warm running-water pond.

The upper diatom complex (points 9150, 9151, L03/1-L03/3, L04/1) differs from the lower one by the absence of many subtropical species (Actinella brasiliensis, Cymbella australica (A.Schmidt) Cleve, Desmogonium guianense Ehrenb., D. rabenhorstianum Grunow) and the growth of diversity and frequency of bottomliving diatoms, especially genera Tetracyclus (Figure 3(C), (F)-(H)), Staurosira Ehrenberg, Planothidium Round et. L.Bukhtiyarova which are typical rheophil forms. Among Tetracyclus flora, there is a predominance of Tetracyclus clypeus (Ehr.) Li Jia-Ying (Figure 3(D), (E)) (up to 62\% - 70\%). Another feature of the upper complex is that planktonic Miosira jouseana is missed out here, whereas M. areolata (Figure 3(A)) is abundant (frequency up to 4). In fact, this interval of sediments can be considered an acme-zone for Miosira areolata. Dominant role belongs to planktonic species Aulacoseira praegranulata (Jouse) Moiss. and Melosira undulata (Ehr.) Kuetz.

Compared to the lower complex, the upper one has got poor species diversity, indistinct morphological boundaries within polymorphic species belonging to genera Aulacoseira, Melosira C. Agardh, Tetracyclus, and a pronounced dominant species. All this is an evidence of more stable conditions for diatom living.

The both complexes are characterized by high polymorphism among Tetracyclus, which is rare for sedimen- 


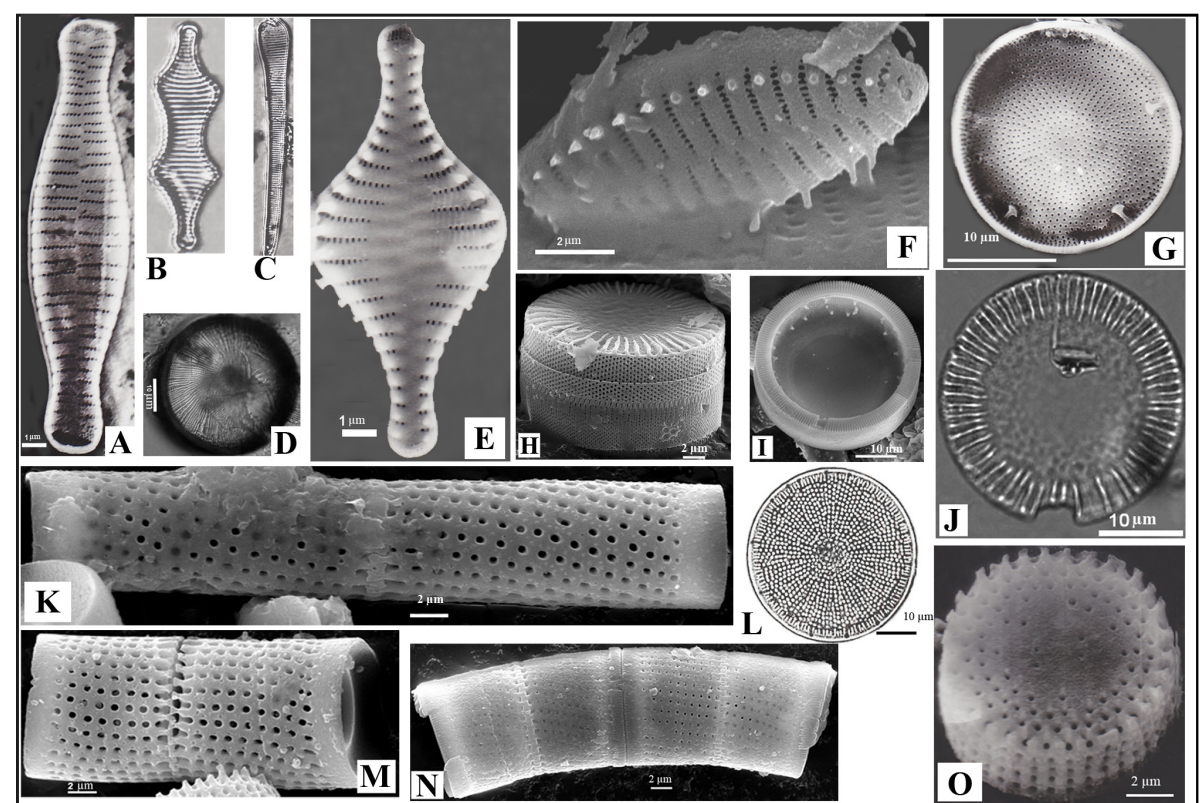

Figure 2. Some representatives of the lower diatom complex. (A) External view of Fragilariforma bicapitata, SEM (scanning election microscope). (B) External view of Fragilaria miocenica var. miocenica, LM (light microscope) $\times 1000$. (C) External view of Actinella brasiliensis, LM $\times 1000$. (D) External view of Melosira undulata var. undulate, LM. (E) External view of Staurosira construens, SEM. (F) External view of Staurosira venter, SEM. (G) Internal view of Actinocyclus gorbunovii: a valve with a several labiate processes, SEM. (H) Ellerbeckia arenaria f. terres-a valve mantle with a cingulum, SEM. (I) Ellerbeckia arenaria f. terres - internal surface with a ring of tubulate processes, SEM. (J) External view of Ellerbeckia arenaria f. terres, LM. (K) Aulacoseira praegranulata var. praegranulata f. praegranulata - a valve mantle, SEM. (L) External view of Mesodictyon fovis, SEM. (M) Aulacoseira praegranulata var. praeislandica f. praeislandica-a valve mantle, SEM. (N) Aulacoseira praegranulata var. praeislandica f. curvata - a valve mantle, SEM. (O) External view of Miosira jouseana, SEM.

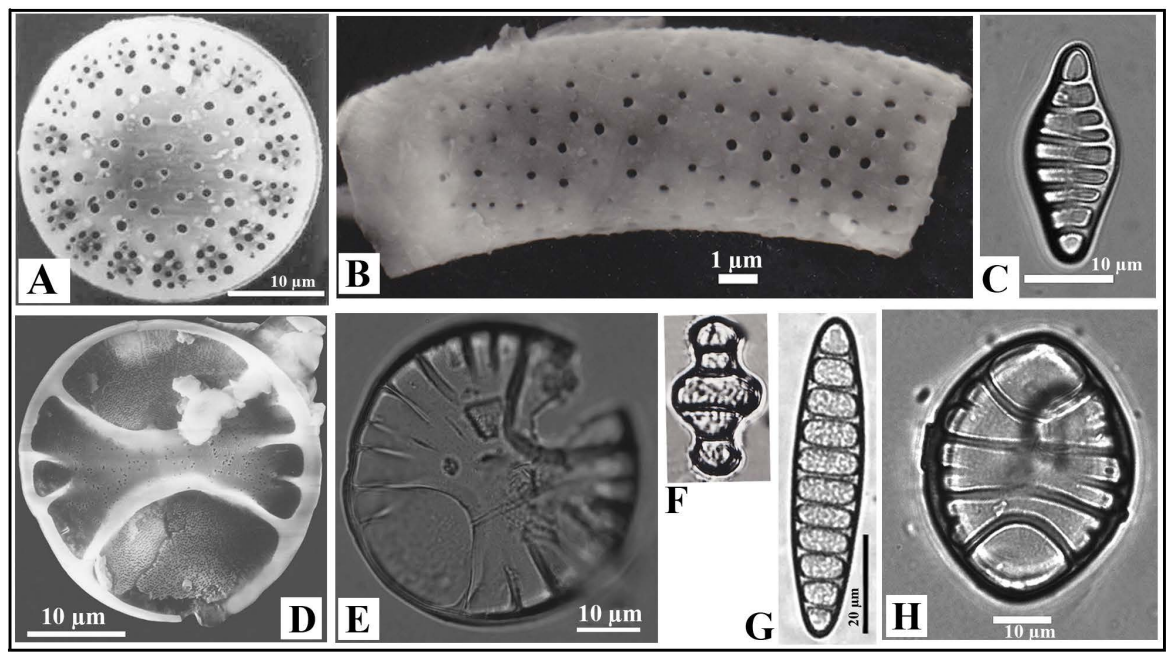

Figure 3. Some representatives of the upper diatom complex. (A) External view of Miosira areolata, SEM. (B) Aulacoseira taiganosica-a valve mantle, SEM. (C) External view of Tetracyclus ellipticus var. lancea, LM. (D) Internal surface of Tetracyclus clypeus, SEM. (E) Internal surface of Tetracyclus clypeus, LM. (F) External view of Tetracyclus lacustris var. lacustris, LM $\times 1000$. (G) Tetracyclus sp., LM. (H) External view of Tetracyclus excentricum, LM. 
tary rocks of other age in Primorye, and by presence of only here found Aulacoseira taiganosica (Figure 3(B)) Lupikina et Ozorn., that can be considered as an important reference feature for these deposits.

From the position of paleogeography, a contrast between two complexes can be explained by the progressing fall of temperature and predominance of fluvial-lakustrine sedimentation over the typically lake one due to development of a wide system of river valleys. The low degree of absolute dominance under sufficient species diversity and high uniformity level is a marker of fast changing in environmental conditions. It is possible that at this time span the winter monsoon starts prevailing under the summer one that affected the nature of lake basins watering.

\section{Acknowledgements}

The author thanks two researches from Far East Geological Institute FEB RAS: Prof. Pushkar V.S. for his ideas during implementation of this study and Prof. Pavlyutkin B.I. for his help in the organization of field works and consultations about regional stratigraphy. Many thanks go also to Dr. Cherepanova M.V. from Institute of Soil Biology FEB RAS for her invaluable assistance in identifying of diatoms valves, consultation on scanning microscopy and in the area of taxonomic analysis.

This work was supported by Russian Foundation for Basic Research (RFBR) grant №14-05-31195 and Far Eastern Branch Russian Academy of Sciences (FEB RAS) grant №14-III-B-08-180.

\section{References}

Cherepanova, M. V., Usol’tseva, M. V., Pushkar, V. S., \& Dubrovina, Yu. F. (2010). Morphogenesis in Cyclotella ocellata Complex from Lake El'gygytgyn (Chukchi Peninsula) during the Pleistocene-Holocene. Paleontological Journal, 44, 1252-1261. http://dx.doi.org/10.1134/S0031030110100035

Douglas, M. S. V., \& Smol, J. P. (1999). Freshwater Diatoms as Indicators of Environmental Change in the High Arctic. In E. F. Stoermer, \& J. P. Smol, Eds., The Diatoms: Applications for the Environmental and Earth Sciences (pp. 227-244). Cambridge: Cambridge University Press.

Glezer, S. I., Jousé, A. P., Makarova, I. V., Proschkina-Lavrenko, A. I., \& Sheshukova-Poretskaya, V. S. (Eds.) (1974). The Diatoms of the USSR (Fossil and Recent) (Vol. I). Leningrad: Publishing House "Nauka”, 400 p. (in Russian)

Glezer, S. I., Makarova, I. V., Mosseeva, A. I., \& Nikolaev, V. A., (Eds.) (1992). The Diatoms of the USSR (Fossil and Recent) (Vol. II). Fasc. 2: Leningrad: Publishing House "Nauka”, Leningrad Branch, 128 p. (in Russian)

Jousé, A. P. (1952). On the Stories of Diatom Flora of Lake Hanka. Materials on Geomorphology and Paleogeography of the USSR. Moscow: Academy of Sciences of the USSR, Institute of Geography of the USSR. 226-252.

Jousé, A. P. (1962). Stratigraphic and Paleogeographic Investigations in the Northwest Part of the Pacific Ocean. Moscow: Akademija Nauk SSSR, Oceanologic Institut, 258 p. (in Russian)

Khursevich, G. K. (1994). Morphology and Taxonomy of Some Centric Diatom Species from the Miocene Sediments of the Dzhilinda and Tunkin Hollows. Memoirs of the California Academy of Sciences, 17, 269-280.

Krammer, K. (1991). Morphology and Taxonomy of Some Taxa in the Genus Aulacoseira Thwaites (Bacillariophyceae). I. Aulacoseira distans and Similar Taxa. Nova Hedwigia, 52, 89-112.

Krammer, K., \& Lange-Bertalot, H. (1991). Süßwasserflora von Mitteleuropa. Bacillariophyceae: Centrales, Fragilariaceae, Eunotiaceae. Band 3. Stuttgart, Jena: VEB Gustav Fischer Verlag, 576 p.

Kuzmin, M. I., Khursevich, G. K., Prokopenko, A. A., Fedenya, S. A., \& Karabanov, E. B. (2009). Centric Diatoms of the late Cenozoic Lake Baikal: Morphology, Systematics, Stratigraphic Distribution, Stages of Development (Based on DeepWater Drilling). Novosibirsk: Publishing House “GEO”, 374 p. (in Russian).

Likhoshway, Ye. V., Pomazkina, G. V., \& Nikiteeva, T. A. (1997). Centric Diatoms from the Miocene of the Baikal Rift Zone (Tunkinskaya Basin). Geology and Geophysics, 38, 1445-1452. (in Russian).

Moisseeva, A. I. (1971). Atlas of Neogene Diatom Algae of Primorye. Leningrad: Nedra, 152 p. (in Russian).

Moisseeva, A. I. (1995) Subdivision of the Neogene Continental Sediments of the Far East Based on Diatoms. Stratigraphy and Geological Correlation, 3, 92-103. (in Russian).

Pavlyutkin, B. I., Pushkar, V. S., Cherepanova, M. V., \& Petrenko, T. I. (2004). The Miocene Stratigraphy Problems of the Khanka Depression of Primorye, Russian Far East. Russian Journal of Pacific Geology, 23, 73-85. (in Russian).

Pavlyutkin, B. I., Ganzei, S. S., Pushkar, V. S., \& Petrenko, T. I. (1993). Paleobotanical Characteristics and Radiomety of the Neogene Sediments in Southen Primorye. Stratigraphy and Geological Correlation, 1, 40-47. (in Russian).

Pushkar, V. S., \& Cherepanova, M. V. (2001). The diatoms of Pliocene and Anthropoge of North Pacific (Stratigraphy and 
Paleoecology). Vladivostok: Dal'nauka, 228 p. (in Russian).

Pushkar, V. S., Cherepanova, M. V., \& Likhacheva, O. Yu. (2013). Detalization of the Pliocene-Quaternary North Pacific Diatom Zonal Scale. Russian Journal of Pacific Geology, 32, 51-65. (in Russian).

Rasskazov, S. V., Lyamina, N. A., \& Chernyaeva, G. P. (2007). Cenozoic Stratigraphy of Vitim Plateau: The Phenomenon of Long Rift in the South of Eastern Siberia. Novosibirsk: Publishing House “Geo”, 193 p. (in Russian).

Temniskova-Topalova, D. N., Kozyrenko, T. F., Moiseeva, A. I., \& Sheshukova-Poretskaia, V. S. (1981). The New Genus Pontodiscus Bacillariophyta. Botanical Journal, 66, 1308-1311. (in Russian).

(1994). The Resolution of the 4th Interdepartmental Stratigraphic Meeting on the Cryptozoic and Phanerozoic South of the Far East and Eastern Transbaikalia. Khabarovsk: HGGGP, 124 p. (in Russian)

Williams, D. M. (1989). Observations on the Genus Tetracyclus Ralfs (Bacillariophyta) II. Morphology and Taxonomy of Some Fossil Species Previously Classified in Stylobiblium Ehrenberg. British Phycological Journal, 24, 317-327. http://dx.doi.org/10.1080/00071618900650331

Williams, D. M. (1996). Fossil Species of the Diatom Genus Tetracyclus (Bacillariophyta, “Ellipticus” Species Group): Morphology, Interrelationships and the Relevance of Ontogeny. Philosophical Transactions of the Royal Society, 351, 1759-1782. http://dx.doi.org/10.1098/rstb.1996.0156 